\title{
Dysphagia following prolonged mechanical ventilation and tracheostomy in critical ill patients. results of edisval study pilot phase
}

\author{
A Fernández Carmona ${ }^{1 *}$, I Macías Guarasa², R Gutiérrez Rodríguez², P Martínez López³ , MA Díaz Castellanos ${ }^{4}$, \\ EDISVAL Group
}

From ESICM LIVES 2015

Berlin, Germany. 3-7 October 2015

\section{Introduction}

Available data shows that dysphagia and swallowing disorder rate secondary to artificial airway and prolonged mechanical ventilation in critical tracheostomized patients is high (50-83\%), nevertheless it real incidence is not yet well established. Dysphagia is directly related to bronchial aspirations and respiratory infections. The rate of respiratory infections on tracheostomized patients is also very high (Some series next 100\%). The re-establishment of airway using speaking valves allow the rehabilitation and post-recovery of those disorders, as well as deglutition and phonatory system rehabilitation.

The aim of EDISVAL Study is to determine the usefulness of speaking valve in preventing respiratory nosocomial infections in critical tracheostomized patients diagnosed of dysphagia secondary to artificial airway, for what it was done a screening test of dysphagia to the critical tracheostomized patients.

\section{Objectives}

To describe the incidence of swallowing disorder secondary to artificial airway and prolonged mechanical ventilation in critical patients who require tracheostomy.

\section{Methods}

From September 2014 until December 2014, in all patients over 18 years, during mechanical ventilation weaning-decannulation phase, without neurological or surgical disease which could contribute to the appearance of dysphagia, there was realized the Modified Evans Blue Dye Test (MBDT) as dysphagia screening test. This study was carried out of simultaneous form in 7 intensive care units including first, second and third level centers.

\section{Results}

Mean age average of the patients was 71,6 years, the initial APACHE'S average was 21.2. Mean time of mechanical ventilation was 23,6 days. During the study period we studied 29 patients by MEBDT, 27 patients were diagnosed of dysphagia, and included to the EDISVAL study; we did not carry out other specifics test of dysphagia to discriminate a possible MEBDT false negative.

In the patients with negative MEBDT, not diagnosed of dysphagia, respiratory infections were not registered.

In the patients diagnosed of disfagia included at EDISVAL study, in spite of strict measures for it prevention, including absolute oral diet, 7 respiratory infections were registered, 2 catalogued as tracheobronchitis and 5 as pneumonia. 3 of the patients who suffered respiratory serious infections died during hospital stay.

\section{Conclusions}

The dysphagia secondary to artificial airway incidence in our series was 93,4\% according to the Modified Evans Blue Dye Test. Respiratory infections were a frequent complication in the patients diagnosed of dysphagia, with a probable repercussion in the mortality of the patients.

\section{Authors' details \\ ${ }^{1}$ Virgen de las Nieves Hospital, Granada, Spain. ${ }^{2}$ Hospital Carlos Haya, Malaga, Spain. ${ }^{3}$ Hospital Virgen de la Victoria, Malaga, Spain. ${ }^{4}$ Hospital Santa Ana,} Motril, Spain.

Published: 1 October 2015

${ }^{1}$ Virgen de las Nieves Hospital, Granada, Spain

Full list of author information is available at the end of the article 


\section{References}

1. Romero CM: Swallowing dysfunction in nonneurologic critically ill patients who require percutaneous dilatational techeostomy. Chest 2010, 137.

2. Fernández A: Exploration and approach to artificial airway dysphagia. Med Intensiva 2012, 36

doi:10.1186/2197-425X-3-S1-A677

Cite this article as: Fernández Carmona et al: Dysphagia following prolonged mechanical ventilation and tracheostomy in critical ill patients. results of edisval study pilot phase. Intensive Care Medicine Experimental 2015 3(Suppl 1):A677.

\section{Submit your manuscript to a SpringerOpen ${ }^{\circ}$ journal and benefit from:}

- Convenient online submission

- Rigorous peer review

- Immediate publication on acceptance

- Open access: articles freely available online

- High visibility within the field

- Retaining the copyright to your article

Submit your next manuscript at $\gg$ springeropen.com 